\title{
Negative economic shocks and child schooling: Evidence from Rural Malawi ${ }^{1}$
}

\author{
Asma Hyder [Assistant Professor], \\ Karachi School for Business \& Leadership, Karachi School for Business \& Leadership, National \\ Stadium Road, Opp. Liaquat National Hospital, Karachi - 74800, Pakistan, UAN: (92 21) 11111 \\ KSBL (5725), PABX: (92 21) 34855382 Ext: 701, Fax: (92 21) 34922831, asma.baloch@ksbl.org, \\ URL: www.ksbl.edu.pk
}

Jere R Behrman, and William R, Kenan, Jr Professor of Economics and Sociology and Research Associate, Population Studies Center, University of Pennsylvania, USA., jbehrman@econ.upenn.edu

\section{Hans-Peter Kohler}

Frederick J. Warren Professor of Demography, Sociology Department, Research Associate, Population Studies Center, University of Pennsylvania, USA., hpkohler@pop.upenn.edu

\section{Abstract}

This study investigates the impacts of negative economic shocks on child schooling in households of rural Malawi, one of the poorest countries in Sub-Saharan Africa (SSA). Both individuallyreported and community-level shocks are investigated. There is evidence that community level shocks negatively impact the school enrolment of children. The point estimates suggest that this effect is larger when shocks and school enrollment are reported by men as compared to women. But we cannot conclude with statistical confidence that the impact of idiosyncratic shocks is larger when reported by males than when reported by females. Similarly, although the point estimates suggest that the impact of community level shocks on the school enrolment of children is larger than that of idiosyncratic shocks, we cannot conclude with statistical significance that the impacts of community-level and idiosyncratic shocks are different.

\section{Keywords}

Africa; economic shocks; child schooling

\section{Introduction}

The income volatility in developing countries originates in many aggregate and idiosyncratic negative shocks including adverse weather conditions, poor crop yields, and unstable prices. The aggregate shocks may be at the level of the community, the region or the whole

\footnotetext{
${ }^{1}$ Authors acknowledge and are thankful for supporting this research to National Institutes of Health Grant R01HD053781 (P.I. HansPeter Kohler) and to Grand Challenges Canada Grant 0072-03 (P.I. Jere R. Behrman). 
economy so that community-wide or broader support networks may not be able to provide much help to those affected negatively. Idiosyncratic shocks may be very localised - for example with heterogeneous soil, drainage and topographical conditions meaning that for given local weather conditions crops grown on one field may be affected substantially but those in a neighbouring field not affected much or at all. If there are strong gender roles in a society, shocks perceived by males may have different effects on child schooling than shocks reported by women.

The previous literature shows an ongoing debate about the importance of negative economic shocks, including the importance of aggregate versus idiosyncratic shocks, in affecting child schooling. Ferreira and Schady (2009), for example, note that the sign of effects of aggregate negative economic shocks on investment in schooling are theoretically ambiguous because of a tension between income and substitution effects. Most empirical studies find that negative aggregate economic shocks have adverse effects on child schooling, suggesting that income effects dominate (Escobal. et al. 2005 and Fallon and Lucas, 2002). Duryea and Arends-Kuenning (2003) for urban Brazilian children, Jensen (2000) for Cote d'Ivoire Jacoby and Skoufias (1997) for households in India, Sawada and Lokshin (1999) for Pakistan, Beegle et al. (2006) for Tanzania and Flug, Spilimbergo, and Wachtenheim (1998) for cross-country panel data from 88 countries for 1970-92 and find that income and employment volatility had significant negative effects on school enrolment in low-income countries.

But there are some, though fewer, empirical studies of the impact on schooling of negative aggregate economic shocks that find positive effects, consistent with the price effect dominating the income effect. High school enrolment and graduation rates increased during the Great Depression in the United States (Goldin, 2001 and Black and Sokoloff, 2006). School attendance increased during the Mexican Peso crisis and the Thai financial crisis of the mid 1990s (McKenzie 2003; Behrman, Deolalikar and Tinakorn 2007). Similarly Lopez Boo (2012) finds that the probability of being in school (and not working) increased by 6 percentage points over the 1998-2002 crisis period in Argentina.

In addition to the literature summarised above on the impact of negative shocks on schooling, there also is a literature that argues that idiosyncratic shocks may leave consumption expenditures unaffected because of pooling of risks at the community level (Cochrane (1991), Mace (1991), Pan (2007), Townsend (1994). Townsend (1994) describes potential risk-bearing procedures used by households, which include spatial diversification of land holdings, storage of grains from one year to the next, purchases and sales of assets such as bullocks and land, credit from formal and informal sources and gifts and transfers within family and community networks. He uses the International Crop Research Institute for the Semi-Arid Tropics (ICRISAT) Village Level Studies (VLS) data and finds support for pooling idiosyncratic risks in that household consumption is related more strongly to community-level pooled income than to individual-household income. Pan (2007) similarly finds that negative idiosyncratic shocks to household income in rural Ethiopia are insured by pooling risk.

Our contributions in this study are: 
First, we provide estimates of the impact of negative shocks on child schooling for a different context than considered in previous studies, which is important because as noted the context probably matters for determining even the sign of the effects. In particular, we study a much poorer society in which formal market and governmental institutions to buffer shocks are likely to be relatively underdeveloped in comparison with contexts considered in most previous studies. We consider rural Malawi, a fragile state both in terms of physical and human capital. Malawi is relatively poor, even by African standards. It ranks 153 (out of 169) on the Human Development Index, which is below the regional average, and its GDP per capita was $\$ 902$ in 2008 (US\$ purchasing power parity) compared to an average of $\$ 3,845$ for sub-Saharan Africa (UNDP 2010). The percentage of each birth cohort that advances to the last grade of primary school is only 35\% for girls and 37\% for boys (World Bank, 2006). Malawi's agriculture accounts for about $40 \%$ of the economy's production, almost $90 \%$ of the employment and is mostly rain-fed maize production (Syroka and Nucifora 2010) that is vulnerable to fluctuations in weather conditions.

Second, we estimate the impacts of both idiosyncratic and aggregate community shocks. The previous literature, as noted, has focused primarily on aggregate shocks, though with some studies of pooling idiosyncratic shocks. But, as also noted, individual households may experience substantial negative economic shocks that are not manifested strongly at the community level and a priori responses to shocks may differ substantially depending on whether the shocks are idiosyncratic or aggregate because the former may be buffered by community support networks that are not very effective for the latter and because the latter are likely to have price in addition to income effects. Indeed it is not clear a priori whether the effects of idiosyncratic or aggregate shocks are likely to be larger. If, as seems plausible based on knowledge of the heterogeneities of communities such as being studied, measured aggregate shocks are effectively (if not necessarily, literally) the average of individual shocks that vary considerably within the communities, the use of individual idiosyncratic shocks rather than community averages may yield larger estimated effects because the individual shocks may represent with less measurement error what individual households experience. On the other hand, as noted several times, if there are important community support networks, then it would seem that these networks would be much more effective in buffering idiosyncratic rather than community-level shocks. Moreover, as also noted, aggregate shocks are more likely to have price effects through local labour markets that may partially or entirely offset the income effects due to the shocks.

Third, we consider the estimated effects of shocks reported by men versus those reported by women. These may differ, as noted, if there are strong gender roles in knowledge about household income shocks or the relevance of such shocks for investing in children. The estimated effects of shocks reported by men versus those reported by women also may differ if the coping mechanisms used differ for men versus women (Quisumbing, et al. 2011). For example, Goldstein (1999) shows that women pool their risk with other women in the same village while men have a less defined risk pool. Similarly, using the same data that we use (i.e., Malawi Longitudinal Study of Families and Health, MLSFH) Kohler et al. (2011) report that financial transfers to mothers from adult children and from parents to female respondents are greater than those to male respondents. These differences in coping mechanisms and the locality of risk sharing pools might imply that responses to women- 
reported shocks might be smaller than response to make-reported shocks. But such differences have not been the subject of previous studies of the impacts of shocks on child schooling.

\section{Framework for analysis}

We have in mind a very simple human capital investment framework as in the well-known Becker (1967) Woytinksy Lecture. Consider Figure 1 in which the expected private marginal benefits and expected private marginal costs are measured on the vertical axis and schooling investments in children are measured on the horizontal axis. The expected private marginal benefits are downward-sloping as schooling increases in the relevant range due to diminishing marginal returns to fixed abilities and pre-schooling investments. The expected private marginal costs are increasing due to increasing private opportunity costs of more schooling in terms of other time use options (e.g. working on family farms, caring for younger siblings) and possibly increasing marginal costs of financing current schooling investments given imperfect or missing capital markets for such investments. The equilibrium private investment in schooling $\mathrm{S}^{*}$ is given by the intersection of the expected private marginal benefits and expected private marginal private costs curves as for the solid lines in Figure 1, with the equilibrium expected private marginal benefits and expected private marginal costs equal to $r^{*}$.

Idiosyncratic negative shocks may move the expected private marginal cost curve in either direction, and thereby change the equilibrium private schooling investment and the equilibrium expected private marginal benefits and equilibrium expected private marginal costs in either direction (but the opposite direction for the equilibrium private schooling investment versus the equilibrium expected private marginal benefits and equilibrium expected private marginal costs). The direction in which the expected private marginal cost curve shifts depends on whether the price effect or the income effect of the idiosyncratic negative shock dominates. If the price effect -- for example in the form of the opportunity cost of time going to school -- dominates, the expected private marginal cost curve shifts down due to less aggregate labour market demand and the equilibrium schooling investment increases and the equilibrium expected private marginal costs and expected private marginal benefits decrease (Figure 2). If the income effect -- perhaps because schooling must be family-financed in the absence of access to capital markets for human capital investments -dominates, the expected marginal private cost curve shifts up, the equilibrium schooling investment decreases, and the equilibrium expected marginal private costs and expected private marginal benefits increase (Figure 3).

Shocks reported by individuals may be either truly idiosyncratic or affect some broader community. Given the limited water-control and idiosyncratic growing conditions in the semi-arid tropics, for example, a particular configuration of weather events may result in negative shocks for one farmer but not for neighbours. But a different configuration of weather events may result in negative shocks for the same farmer and all the neighbours. In some respects, if an individual reports a negative shock that, say, shifts the expected private marginal costs curve by a certain magnitude, from the individual point of view it may not be important whether it is idiosyncratic or for a wider community. His or her expected private 
marginal costs and expected private marginal benefit curves shift, with concomitant implications for equilibrium schooling investments. But if other community members provide informal insurance and the negative shocks are for a broader community rather than idiosyncratic, then, for example, the community insurance function is likely to be reduced and the income impact of the shock intensified. If the price effect would have dominated in the absence of the community income and support effects, then the magnitude of the change in the equilibrium schooling investment either is reduced (if the price effect still dominates once the community effect is incorporated) or reversed (if the income effect dominates once the community effect is incorporated). If the income effect would have dominated in the absence of the community income effect, the absolute value of the magnitude of the change in the equilibrium schooling investment is increased. Thus negative community-wide shocks, e.g. changes in price levels, are likely to result in smaller positive (if the price effect dominates) or larger negative changes in equilibrium schooling investments (if the income effect dominates) than negative idiosyncratic shocks.

Negative shocks also may operate through shifting the expected private marginal benefits curve. For instance, negative shocks - presumably more so for community shocks than for idiosyncratic shocks - might reduce expected future returns from schooling investments and thereby shift the expected private marginal benefit curve downward and reduce equilibrium schooling investment and equilibrium expected private marginal costs and equilibrium expected private marginal benefits.

A further consideration for analysis with the data that we use is who reports the shocks because there appear to be strong gender roles in the society that we examine. If men have relatively large roles in making decisions about income generation for the household as is sometimes hypothesized, then they may be more likely to reports events as negative shocks that have price and/or income effects on household resources. On the other hand if women are more involved in human capital investment in children, they may be more sensitive to the types of negative shocks that affect such investments.

\section{Data}

Our analysis is based on data from the Malawi Longitudinal Study of Families and Health (MLSFH; formerly, Malawi Diffusion and Ideational Change Project), a longitudinal panel survey with survey waves in 1998, 2001, 2004, 2006, 2008 and $2010^{2}$ that is being implemented in three sites in rural Malawi: Rumphi (in the northern region), Mchinji (in the central region), and Balaka (in the southern region). Although the sampling strategy was not designed to be representative of rural Malawi, the sample characteristics closely match those of the rural population of the nationally-representative Malawi Demographic Health Survey (DHS) (Bignami-Van Assche et al. 2003, Anglewicz et al. 2009) ${ }^{3}$. The first survey wave in 1998 collected information on 1,539 ever-married women ages 15-49, and 1,066 spouses.

\footnotetext{
${ }^{2}$ The 2010 data were not available in time for this study.

${ }^{3}$ Detailed descriptions of the MLSFH/MDICP sample selection, data collection, and data quality are provided on the project website at http://www.malawi.pop.upenn.edu, in a Special Collection of the online journal Demographic Research that is devoted to the MDICP (Watkins et al. 2003), and in a "Cohort Profile" (Kohler et al. 2014).
} 
Both husbands and wives responded separately to the survey, thus permitting us to investigate whether it makes a difference who provides information on shocks.

We analyse a panel of children between 6 to 15 years of age in 2008 based on information from male and female respondents respectively for the years 2006 and 2008. To allow for longitudinal analyses, the data on respondents' children listed in the 2006 and 2008 MLSFH family and transfer rosters were linked using names, ages, sex, and birth order (Castro 2010). Because not all data were available in every wave, and because the spelling of names is not always exactly identical across waves, the matching was not undertaken with a computerised algorithm, but was done case-by-case instead. Two processes were undertaken simultaneously. First, names were designated the principal matching variable; so to be consider matched, a minimum similarity in spelling was required. Second, a quality indicator for the quality of the match was assigned to each matched child, with the match being low quality if no other data than the spelling itself was available to establish the match, and the spelling itself was of limited similarity across waves, medium quality if any other variable was available (age, sex, birth order) to establish the match or, if no other data were available but the spelling matched very closely, and high quality if two or more variables were available to establish the match. Only children of medium- and high-quality matches, which represent about $90 \%$ of the total matched cases, are included for the analyses of this paper. In total, over 5,300 children were matched between the 2006 and 2008 waves. After excluding those with low-quality matches and those below 6 years and above 15 years of age in 2006 we are left with 2575 children (1069 reported by male and 1506 by female respondents) in the 2006 wave and 2316 children (1148 reported by male and 1668 by female respondents) in the 2008 wave on which we focus in this paper.

Table 1 and 2 gives the means and standard deviations and variable definitions for the key variables that are used in our analysis.

\section{Child schooling}

Primary school is compulsory. There are no fees, though of course there are costs due to such factors as transportation and books and other materials Primary school usually starts at ages 5 or 6 and takes at least 8 years, often longer due to grade repetition, from Standard 1 to Standard 8. There is a high priority placed on learning English in Malawi and all subjects are taught mainly in English from Standard 5 onwards.

Secondary schooling covers four grades (Form 1 to Form 4). Secondary students take a Junior Certificate Examination (JCE) in Form 2 and a Malawi School Certificate Examination (MSCE) in Form 4. The quality of secondary education varies widely. In general, fees in private schools are more than 50 times that in public schools. For a long time, secondary education was very limited in Malawi but this situation is changing due to rapid expansion of private schools as well as government-run community day secondary schools. However, the schooling system in Malawi faces many challenges (Isaacs 2007).

We use two alternative dependent variables for child schooling outcomes. 
The first child schooling outcome variable used is current enrolment, "Is (Name) currently in school? 1=yes and zero otherwise". In $200685 \%$ and $86 \%$ of children were enrolled in schools and in 2008, $91 \%$ and $89 \%$ of children were enrolled in schools reported by male and female respondents respectively. There are slight declines in the enrolment rates as children age over the 6-15 year-old age range, with about $97 \%$ of children reported enrolled for ages $6-8$ years and $92 \%$ for ages $13-15$ years.

The second child schooling outcome variable is the "grade attainment gap". This variable is constructed based on two questions. The first question is, "What is the highest level of schooling (Name) attended?" and the second question is, "How many grades (in years) did (name) complete at that level?" For the grade attainment gap analysis we calculate the difference between 'actual age when last grade attained by child' and 'the age at which that grade should have been achieved were the child to start school at age 6 years and progress one grade every subsequent year'. On average the absolute magnitudes of grade attainment gaps were almost one grade in 2006 and about 1.9 grades in 2008, with fairly large variance within the sample (i.e., standard deviations of about 1.8 grades). There are strong agespecific patterns in the grade attainment gaps. Children 6 and 7 years old on average have positive values because of the tendency for many children to be enrolled in school before they are 6 years old. But older children on average have negative values that average greater than 2 grades in absolute magnitudes by age 12 and greater than 3 grades in absolute magnitudes by age 14, reflecting fairly high rates of repeating grades and of dropping out of school.

\section{Economic shocks}

In 2008 the MLSFH questionnaire included a section about negative economic shocks faced by households, including the timing, during the five years immediately prior to the survey. In particular, the survey asked the question: "Over the past five years, was your household severely affected negatively by any of the following unexpected events or crises?", where the unexpected events/shocks included: Poor crop yields, loss of crops due to disease or pests, or loss of livestock due to theft or disease, etc.; loss of source of income-such as loss of employment, business failure, someone who had been assisting the household stopped their support; and big change in price of grain (either increase or decrease) ${ }^{4}$. Only the 2008 survey included the section on negative economic shocks. Thus the information provided in the 2008 wave is also used for 2006. The first question of the 2008 section on economic shocks was "Over the past five years, was your household severely affected negatively by any of the following unexpected events or crises?" and the next question was "When did this shock occur (year)?", which allowed us to identify the relevant shocks (2006 and 2007 for the 2008 wave and 2004 and 2005 for 2006 wave) for our analysis. Moreover, respondents were asked to report negative shocks but without explicit attention to and particular consequences for child schooling. Rather the next question in the survey was "Did this shock cause reduction in household income, assets, both or none?" We are also exploiting this question and using any shock that caused loss of income or assets. Thus for the year

\footnotetext{
${ }^{4}$ These types of shocks are what the respondents reported, NOT the "price effects" and the "income effects" in economic models of household behaviours and that are discussed above in Section 2 on the framework for our analysis.
} 
2006 we are defining the shock to be 1 if any shock occurred in 2004 and 2005 that caused loss of income or assets. Previous studies used a variety of methods to measure such shocks. Some examples are; standard deviation of crop profit (Kochar 1999), scale measurement of climatic shock (Takashi 2011), harvest quantity to measure the crop shock (Eozenov 2008) and self-reported shocks (Borner et al 2012). The negative economic shocks in the present study are self-reported shocks based on the perceptions of the male and female respondents.

We study the impacts on child enrolment and grade attainment of reporting having experienced any negative economic shock. We define idiosyncratic shocks to be shocks reported by individual respondents (measured in categorical form) and aggregate shocks to be community means indicating what proportion of households in the sample in each village experienced any shock (measured in continuous form) in each of the 145 villages in the $\mathrm{MLSFH}^{5}$. The aggregate shocks allow us to examine how widely individual-reported shocks were perceived by other sample households in the same community. ${ }^{6}$

\section{Control Variables}

One possible problem with utilising respondent-reported data on when negative economic shocks were experienced is that whether a particular event is perceived and reported by a respondent to be a shock or not may depend on respondents' characteristics such as wealth and schooling. For example, a price change that is viewed as a big economic shock by a respondent with very limited wealth and no schooling may be viewed less negatively by a respondent with more wealth and schooling. If there were no control for such possibilities the coefficient estimates of the reported idiosyncratic shock variable may reflect in part the correlated wealth or schooling effects, not the impacts of the shocks alone. To attempt to control for such possibilities, we include among our right-side variables household wealth indices and respondents' schooling attainment. The wealth indices were constructed through using the first principal component of a set of dwelling characteristics and ownership of household durable assets ${ }^{7}$ (Pollitt, et al. 1993, Filmer and Pritchett 2001, Vyas and Kumaranayake 2006, Filmer and Scott 2008). To avoid possible endogeneity in the form of wealth being affected by the shocks, we control for the initial wealth indices rather than current wealth indices. Thus we use the 2004 wealth indices for the 2006 survey wave in which we are considering shocks between 2004 and 2006 and the 2006 wealth indices for the 2008 survey wave in which we are considering shocks between 2006 and 2008 . We also explore fixed effects estimates to control for unobserved household factors, but as noted below, Hausman tests do not indicate that fixed effects are preferred to random effects. ${ }^{8}$

The respondents' schooling level, which is measured by a dummy variable, averaged about primary for males but below primary for females, with a fair amount of variance for both males and females. The initial wealth indices also have considerable variation. We also

\footnotetext{
${ }^{5}$ We include all individual responses to calculate community means because the individual responses contribute both to the idiosyncratic shocks (that are the individual responses) and to the community shocks (that are the proportion of individuals in the community that reported shocks).

${ }^{7}$ The dwelling characteristics include whether the house had a metal roof, land area, and livestock. The 18 household durable assets included, for example, sofa, table, lamp, bicycle, television.

${ }^{8}$ Because of the Hausman tests results, we present the random effects estimates in the text. The fixed effects estimates suggest similar qualitative results but with less precision.
} 
control for the children's gender (49-50\% male) and age (mean of about 9.4 years in 2006, 10.8 years in 2008) because schooling may differ by gender and almost certainly varies by age. The age pattern is likely to be nonlinear, so we include a quadratic in age. Finally, we include a "2008" dummy to control for secular trends between 2006 and 2008.

\section{Empirical estimates}

We use Logit estimators for the dichotomous child schooling enrolment outcome (Table 3) and least squares estimators for our continuous child school attainment gap measure (Table 4), but in both cases with right-side variables including whether any shocks were reported (idiosyncratic or community-level in alternative estimates), controls for respondents' characteristics (parental schooling attainment and initial wealth), and child gender and age (a quadratic in age), and child random effects to control for the correlation of the residual over time because our data include two observations (2006 and 2008) per child. For both outcomes we present estimates for children age 6-15 years old in 2008. Each table has estimates in the first set of three columns based on the sample of male respondents and in the second set of three columns based on the sample of female respondents. For both male and female respondents there are three models. The first model includes whether households experienced any idiosyncratic negative shocks, the second model uses the proportion of households in the community with any negative shocks, and the third model includes both the idiosyncratic and the community shocks.

For child enrolment, the estimates indicate significant negative associations for male respondents but not for female respondents of any idiosyncratic shocks. The patterns for the community shocks are similar but the coefficient estimates are much larger in absolute magnitudes and there are significant negative estimates for negative community shocks for both female and male respondents. In addition, in Model 3 for males, the coefficient estimates for 'idiosyncratic negative shock' and 'aggregate community-level negative shock' are jointly significant at the 5\% level of significance.

Our results in Table 3a are similar to Beegle at al (2006) in terms of the direction of estimates but somewhat different in magnitude. For example, Beegle et al report that the children in households affected by a shock are $20 \%$ less likely to be enrolled, but in the present case the children in households affected by idiosyncratic and community shocks as reported by male respondents, respectively, are 30 and $70 \%$ less likely to be enrolled. However, for female respondents the children in households that experienced community shocks are 58\% less likely to be enrolled in school but idiosyncratic shocks have insignificant (though negative) effects on school enrolment. The results for the idiosyncratic shocks are consistent with the possibility noted above that males are better informed about the nature of the household resource constraint. For the community shocks there is ambiguity about whether the impact is larger for male or for female respondents: the absolute magnitude of the estimated coefficient is larger for male respondents if the idiosyncratic shock is not included, but vice versa if it is - and probably there is no significant difference between the male and female coefficient estimates, given the size of the standard errors, in either case. Thus there is no obvious support for the possibility noted above that women have more localised risk pools that are more concentrated with other 
women in the same community and relatives than for men, and thus children's enrolment is more affected when women than when men report aggregate shocks.

For child grade attainment gaps (Table 4), the estimated coefficient patterns are much weaker. Indeed for both idiosyncratic and community level aggregate shocks, the coefficient estimates are not significantly nonzero though all four of the estimates for community shocks are negative. The difference between the results for the schooling grade attainment gap in comparison with enrolments may be due to the fact that the grade attainment gap refers to the accumulative total effect over a longer period of time than the two years for which the shocks are reported.

Among the control variables, the respondents' schooling and initial wealth are significantly positive, so dropping them from the specification would result in underestimates of the absolute magnitudes of the impacts of shocks if the tendency to report shocks is negatively correlated with wealth and schooling. We examine how a one standard deviation change in household wealth index and in respondent primary and secondary schooling affect enrolment for comparison with the estimated impacts of the shock variables (Table 3b). We find that one standard deviation change in the wealth and respondent schooling variables have smaller impacts than the shock variables except for model 4 (female respondents, only idiosyncratic shocks).

There also are significant impacts of the quadratic in the child ages, but opposite in sign for the two outcomes: increasing at a diminishing rate for enrolments and decreasing at a diminishing rate for the schooling attainment gap. Child gender has no significant impact on enrolment, but, at least as reported by female respondents, girls have significantly smaller (i.e., more positive for a variable for which the mean is negative) grade attainment gaps than do boys. That girls have higher schooling grade attainment on average than boys even though they do not have higher enrolments (presumably because boys fail and repeat grades more than do girls) is a widespread pattern in developing countries as noted by Grant and Behrman (2010).

In estimates that are not presented, we also explored the robustness of our results to a number of alternative specifications that we summarise here. We do not find evidence of significant differences in responses to negative shocks by child age groups (6-10 years versus 11-15 years) as might be expected if the older children are at ages at which negative shocks are more likely to permanently terminate their schooling. We do not find evidence of significant differences in responses to negative shocks by gender of children as might be expected if, say, investment in the schooling of girls is more vulnerable to shocks than investment in schooling of boys as has been found for some other human capital investments elsewhere in the developing world (Behrman and Deolalikar 1990). We do not find evidence of significant differences in responses to negative shocks depending on the respondents' schooling level as suggested by previous studies that claim that schooling improves capacities for dealing with shocks (Schultz 1975, Rosenzweig 1995). 


\section{Conclusions}

Relatively imperfect formal capital and insurance markets are thought to be widespread features of developing economies, particularly poorer developing economies. If informal mechanisms for transferring resources over time are costly, negative income shocks might be expected to have important negative effects on investments in child schooling. On the other hand for more aggregate negative shocks there may be a price effect that works in the opposite direction because the opportunity cost of attending school in the form of labour market returns is likely to decrease. Most previous empirical studies have found that schooling declined in the face of negative shocks, consistent with the income effect dominating, though a minority has found that schooling increased, consistent with the price effect dominating. The variety of empirical results reported is not surprising because of heterogeneities across countries in capital, informal insurance, labour and schooling markets, as well as in expected future returns to schooling.

In this study we contribute an examination of the impacts of negative economic shocks on school enrolment and schooling attainment in rural Malawi, a poorer and less developed economy than most of those previously studied in this literature. Although our analyses cannot identify the causal mechanisms in detail, our results suggest significantly negative impacts of negative shocks on school enrolment in this context, consistent with the dominance of income effects. This result adds to what we know about the impacts of negative shocks on schooling in very poor economies.

We also contribute by investigating the differences in responses to idiosyncratic and to aggregate community shocks, the latter of which has been the focus of previous literature. A priori it is possible that the estimated effects of either one is larger. Aggregate shocks are likely to be noisy measures of the actual shocks that households perceive, so the use of aggregate shocks may bias towards zero the estimated impacts on household schooling decisions. On the other hand aggregate shocks probably weaken possible informal support within communities that might help individual households buffer the effects of idiosyncratic negative shocks. Our results indicate that the point estimates for the community effects are much bigger than those for the idiosyncratic effects, consistent with the latter dilution of community support being important, but are not significantly, consistent with the latter dilution of community support being important. This suggests that community support networks are important, and that their effects outweigh the possible downward bias due to the community shock indicators having relatively large measurement error for representing the actual individual household heterogeneous experiences.

We further contribute by investigating whether gender roles mean that who reports the shock is important. We find no statistical significant differences in the estimated effects of negative shocks reported by men and women for the schooling grade attainment gaps, but the estimated impact of negative shocks reported by men on current school enrolment is larger and statistically significant for idiosyncratic, though not community-level estimates, than the estimated impacts of negative shocks reported by women- though the difference between coefficient estimates for shocks reported by men and women is not statistically 
significant. This result is consistent with the possible importance of underlying gender roles in determining the perceptions of what is a negative shock.

While our study thus contributes to understanding about some important dimensions of the impacts of negative shocks on child schooling enrolment in very poor contexts, it also leaves open questions for further exploration about important dimensions of these processes. That we do not find buffering effects of adult schooling and wealth, for example, raises questions about what are the mechanisms through which the negative shocks are working and what are the implications for policies. More generally, that we do find significant negative effects on enrolments of aggregate community shocks suggests that currently informal insurance mechanisms and governmental policies do not eliminate the negative effects of aggregate shocks. This raises the question of whether there might be effective safety-net policies that lessen or eliminate the negative effects on schooling at a cost that makes such policies worthwhile. Policies that are conditional on experiencing such shocks are not likely to be all that effective because of the probable lags in monitoring possible shocks and implementing policies in response. Therefore policies such as conditional cash transfers, in which one of the conditionalities is schooling attendance, may be more promising than policies that are conditional on shocks. Future studies with more extensive data should explore such questions.

\section{References}

Anglewicz, P. PhD dissertation. Philadelphia, PA: University of Pennsylvania; 2007. Migration, risk perception, and HIV infection in Malawi.

Anglewicz P, Adams J, Obare F, Kohler HP, Watkins S. The Malawi Diffusion and Ideational Change Project 2004-06: Data collection, data quality, and analysis of attrition. Demographic Research. 2009; 20(21):503-540. [PubMed: 20148128]

Aitkin M, Longford N. Statistical Modeling in School Effectiveness Studies. Journal of the Royal Statistical Society, Series A. 1986; 149:1-43.

Atemnkeng TJ, Noula AG. Gender and Increased Access to Schooling in Cameroon: A Marginal Benefit Incidence Analysis. Journal of International Women Studies. 2011; 12(1):94-106.

Becker, GS. Human Capital and the Personal Distribution of Income: An Analytical Approach. 2nd edition. Vol. 1975. Ann Arbor: University of Michigan, Woytinsky Lecture; New York: NBER; 1967. p. 94-117.republished in Gary S Becker, Human Capital

Beegle K, Dehejia RH, Gatti R. Child Labor and Agricultural Shocks. Journal of Development Economics. 2006; 81(1):80-96.

Behrman JR, Deolalikar AB. The Intrahousehold Demand for Nutrients in Rural South India: Individual Estimates, Fixed Effects and Permanent Income. Journal of Human Resources. 1990; 25(4):665-696.

Behrman, JR.; Deolalikar, AB.; Tinakorn, P. What Really Happened to Thai Wage Rates During the 1997 Financial Crisis?. In: Klein, LR.; Shabbir, T., editors. Recent Financial Crises: Analysis, Challenges and Implications. Northhampton, MA: Edward Elgar Publishing, Inc; 2007. p. 221-239.

Bignami-Van Assche S, Reniers G, Weinreb AA. An Assessment of the KDICP and MDICP Data Quality. Demographic Research. 2003; S(1):29-76.

Black, SE.; Sokoloff, KL. Long-Term Trends in Schooling: The Rise and Decline of Public Education in the United States. In: Hanushek, E.; Welch, F., editors. Handbook of the Education of Economics. Vol. 1. Elsevier; 2006.

Borner, J.; Shively, G.; Wunder, S.; Wyman, M. How Rural Households Respond to Economic Shocks?. Insight from Hierarchical Analysis Using Global Data; Paper Presented at International Association of Agricultural Economists; Brazil. 18-24 August 2012; 2012. 
Chin B. Income, Health, and Well-Being In Rural Malawi. Demographic Research. 2010; 23(35):9971030. [PubMed: 21359133]

Clark P, Crewford C. The Choice between Fixed and Random Effect Models: Some Considerations for Educational research. The Centre for Market and Public Organization, Working Paper No. 10.240. 2010

Cochrane J. A simple test of consumption insurance. Journal of Political Economy. 1991; 99(5):957_ 976.

Duryea S, Arends-Kuenning M. School Attendance, Child Labor and Local Labor Market Fluctuations in Urban Brazil. World Development. 2003; 31(7):1165-1178.

Eozenov P. Optimal Risk Sharing Under Limited Commitment: Evidence Rural Vietnam. 2008 MPRA Paper No. 12688.

Escobal, J.; Saavedrae, J.; Suárez, P. Working Paper. Young Lives (Project). University of Oxford: DFID; 2005. Economic Shocks and Changes In School Attendance Levels And Education Expenditure In Peru.

Fallon PR, Lucas REB. The Impact of Financial Crises On Labor Markets, Household Incomes, and Poverty: A Review Of Evidence. The World Bank Research Observer. 2002; 17(1):21-45.

Ferreira FHG, Schady N. Aggregate Economic Shocks, Child Schooling, and Child Health. World Bank Research Observer. 2009; 24(2):147-181. (2009) first published online July 8, 2009.

Filmer D, Pritchett L. Estimating Wealth Effects without Expenditure Data Or Tears: An Application To Educational Enrollments In States Of India. Demography. 2001; 38(1):115-132. [PubMed: 11227840]

Filmer, D.; Scott, K. World Bank Policy Research Working Paper 4605. The World Bank; 2008. Assessing Asset Indices.

Flug K, Spilimbergo A, Wachtenheim E. Investments In Education: Do Economic Volatility And Credit Constraints Matter? Journal of Development Economics. 1998; 55:465-481.

Goldin C. Egalitarianism and the Returns to Education during the Great Transformation of American Education. Journal of Political Economy. 1999; 107(6):S65-S94.

Goldstein, M. Mimeo, Department of Agricultural and Resource Economics, University of California Berkeley, and the Economic Growth Center. New Haven, CT, USA: Yale University; 1999. Chop Time No Friends: Intrahousehold and Individual Insurance Mechanisms in Southern Ghana.

Goldstein H. Methods in school effectiveness research. School Effectiveness and School Improvement. 1997; 8(4):369-395.

Kohler H-P, Watkins SC, Behrman JR, Anglewicz P, Kohler IV, Thornton RL, Mkandawire J, Honde H, Hawara A, Chilima B, Bandawe c>, Mwapasa. Cohort Profile: The Malawi Longitudinal Study of Families and Health (Mlsfh). International Journal of Epidemiology. 2014 Mar 16. First published online: 2014.

Mace BJ. Full insurance in the presence of aggregate uncertainty. Journal of Political Economy. 1991; 99(5):928-956.

Monica JG and Behrman JR. Gender Gaps in Educational Attainment in Less Developed Countries. Population and Development Review. 2010; 36(1):71-89.

Jacoby H, Skoufias E. Risk, Financial Markets, and Human Capital in Developing Country. Review of Economic Studies. 1997; 64:311-335.

Jensen R. Agricultural Volatility and Investment in Children. AEA Paper and Proceedings. 2000; 90(2):399-404.

Malawi - IMF Country Report No. 08/3, 2008. International Monetary Fund.

Kohler, IV.; Kohler, H-P.; Behrman, JR.; Kalilani-Phiri, L. Shocks, Family Transfers and YouthTransitions in Rural Malawi. Unpublished manuscript, Population Studies Center, University of Pennsylvania. Presented at the World Bank and Jacobs Foundation conference on "Children and Youth in Crisis" in Marbach; May 5-6. 2011; Germany. 2011.

Kochar A. Smoothing Consumption by Smoothing Income: Hours-of-Work Responses to Idiosyncratic Agricultural Shocks in Rural India. The Review of Economics and Statistics. 1999; 81(1):50-61.

Lopez Boo F. In School or at Work? Evidence from Crisis. Oxford Development Studies. 2012; 40(3): 381-404. 
McKenzie DJ. How do Households Cope with Aggregate Shocks? Evidence from the Mexican Peso Crisis. World Development. 2003; 31(7):1179-1199.

Nuttall DL, Goldstein H, Prosser R, Rasbash J. Differential school effectiveness. International Journal of Educational Research. 1989; 13:769-776.

Pan, L. Risk Pooling through Transfers in Rural Ethiopia. Netherlands: Tinbergen Institute; 2007. Unpublished Research Paper

Pscharopoulos G. Return to Education: A Global update. World Development. 1994; 22(9):13251343.

Pollitt E, Gorman KS, Engle PL, Martorell R, Rivera J, Wachs TD, Scrimshaw NS. Early Supplementary Feeding and Cognition: Effects over Two Decades. Monographs of the Society for Research in Child Development. 1993; 58(7)

Quisumning AR, Kumar N, Behrman JA. Do Shocks Affect Men's and Women's Assets Differently? A Review of Literature and New Evidence from Bangladesh and Uganda. International Food Policy research Institute. 2011 Discussion Paper 01113.

Rosenzweig MR. Why Are There Returns in Schooling? American Economic Review. 1995; 85(2): 153-158.

Sawada Y, Lokshin M. Household Schooling Decisions in Rural Pakistan. World Bank Policy Research Working Paper No. 2541. 1999 Nov.

Schultz TW. The Value of the Ability to Deal with Disequilibria. Journal of Economic Literature. $1975 ; 13(3): 827-846$.

Syroka J, Nucifora A. Debt Markets; Banks \& Banking Reform; Hazard Risk Management; Labor Policies; Insurance and Risk Mitigation. World Bank Policy Research Working Paper, No, WPS 5169. 2010

Takashi, K. PRIMCED Discussion Paper Series, No. 8. Japan: Hitotsubashi University; 2011. Vulnerability of Household Consumption Village-Level Aggregate Shocks in a Developing Country.

Townsend R. Risk and insurance in village India. Econometrica. 1994 May; 62(3):539-591.

Vyas S, Kumaranayake L. Constructing Socio-Economic Status Indices: How to Use Principal Components Analysis. Health Policy and Planning. 2006; 21(6):459-468. [PubMed: 17030551]

UNDP. Human Development Report: The Real Wealth of Nations: Pathways to Human Development. New York: Palgrave; 2010.

Wooldridge, JM. Econometric Analysis of Cross Section and Panel Data. MIT Press; 2002.

World Bank. Country Profile, Malawi. Washington, DC: World Bank; 2006.

\section{Appendix A}

The panel Logit model is:

$$
\begin{aligned}
& \operatorname{Pr}\left(y_{j}=1 \mid x_{j}\right)=\frac{1}{1+e^{x \beta}} \\
& \operatorname{Pr}\left(y_{j}=0 \mid x_{j}\right)=\frac{e^{x \beta}}{1+e^{x \beta}}
\end{aligned}
$$

We use random effects because Hausman tests indicate that fixed effects are not preferred (for more discussion on choices between random and fixed effect models in educational contexts see Clark and Crewford, 2010; Aitkin and Longford, 1986; Nuttall et al., 1989; Sammons et al., 1993; Goldstein, 1997). The panel logit model is used for enrollment estimates for which we have categorical responses i.e., enrolled or not enrolled in school.

For grade attainment, we use random effects regression equations, as follows: 


$$
\text { Yit }=\alpha+\beta \mathrm{Xijt}
$$

The $X$ vector includes respondent and child characteristics, household initial wealth, idiosyncratic and community level aggregate shocks. Yit is grade attainment (measured as a continuous variable i.e., difference between grade attained and the grade that should be attained at that age).

\section{Appendix B}

Logit Estimates with Child-Level Fixed Effects for Current Enrollment for Children Aged 6-15 Years (Standard Errors in Parentheses)

\begin{tabular}{|c|c|c|c|c|c|c|}
\hline \multirow[b]{2}{*}{ Variables } & \multicolumn{3}{|c|}{ Male Respondents } & \multicolumn{3}{|c|}{ Female Respondents } \\
\hline & $\begin{array}{l}\text { Model } 1 \\
\text { (dy/dx) }\end{array}$ & $\begin{array}{l}\text { Model } 2 \\
\text { (dy/dx) }\end{array}$ & $\begin{array}{l}\text { Model } 3 \\
(\text { dy/dx })\end{array}$ & $\begin{array}{l}\text { Model } 4 \\
(\text { dy/dx })\end{array}$ & $\begin{array}{l}\text { Model } 5 \\
\text { (dy/dx) }\end{array}$ & $\begin{array}{l}\text { Model } 6 \\
\text { (dy/dx) }\end{array}$ \\
\hline Idiosyncratic Negative Shock & $\begin{array}{l}-0.39 \\
(0.3443)\end{array}$ & & $\begin{array}{l}-0.36 \\
(0.413)\end{array}$ & $\begin{array}{l}0.041 \\
(0.283)\end{array}$ & & $\begin{array}{l}0.22 \\
(0.302)\end{array}$ \\
\hline $\begin{array}{l}\text { Aggregate Community-Level Negative } \\
\text { Shock }\end{array}$ & & $\begin{array}{l}-0.61 \\
(0.810)\end{array}$ & $\begin{array}{l}-0.12 \\
(0.983)\end{array}$ & & $\begin{array}{l}-1.86^{*} \\
(1.005)\end{array}$ & $\begin{array}{l}-2.08^{*} \\
(1.059)\end{array}$ \\
\hline \multicolumn{7}{|l|}{ Control Variables } \\
\hline Initial Wealth Index & $\begin{array}{l}-0.182 \\
(0.254)\end{array}$ & $\begin{array}{l}0.07 \\
(0.035)\end{array}$ & $\begin{array}{l}0.07 \\
(0.035)\end{array}$ & $\begin{array}{l}0.13 \\
(0.151)\end{array}$ & $\begin{array}{l}0.093 \\
(0.151)\end{array}$ & $\begin{array}{l}0.09 \\
(0.151)\end{array}$ \\
\hline Respondent Primary School & $\begin{array}{l}-0.53 \\
(0.659)\end{array}$ & $\begin{array}{l}-0.55 \\
(0.675)\end{array}$ & $\begin{array}{l}-0.54 \\
(0.695)\end{array}$ & $\begin{array}{l}0.79 \\
(0.616)\end{array}$ & $\begin{array}{l}0.86 \\
(0.615)\end{array}$ & $\begin{array}{l}0.89 \\
(0.616)\end{array}$ \\
\hline Respondent Secondary School & $\begin{array}{l}-0.51 \\
(1.269)\end{array}$ & $\begin{array}{l}-0.49 \\
(1.237)\end{array}$ & $\begin{array}{l}-0.51 \\
(1.27)\end{array}$ & $\begin{array}{l}-0.87 \\
(1.356)\end{array}$ & $\begin{array}{l}-1.00 \\
(1.344)\end{array}$ & $\begin{array}{l}-0.908 \\
(1.350)\end{array}$ \\
\hline Child Age & $\begin{array}{l}1.45^{* *} \\
(0.537)\end{array}$ & $\begin{array}{l}1.50^{* *} \\
(0.532)\end{array}$ & $\begin{array}{l}1.45^{* *} \\
(0.537)\end{array}$ & $\begin{array}{l}2.05^{* * *} \\
(0.433)\end{array}$ & $\begin{array}{l}1.98^{* * *} \\
(0.438)\end{array}$ & $\begin{array}{l}1.97^{* * *} \\
(0.437)\end{array}$ \\
\hline Child Age Squared & $\begin{array}{l}-0.07^{* *} \\
(0.025)\end{array}$ & $\begin{array}{l}-0.06^{* *} \\
(0.025)\end{array}$ & $\begin{array}{l}-0.06^{* *} \\
(0.025)\end{array}$ & $\begin{array}{l}-0.09^{* * *} \\
(0.019)\end{array}$ & $\begin{array}{l}-0.08^{* * *} \\
(0.019)\end{array}$ & $\begin{array}{l}-0.08^{* * *} \\
(0.019)\end{array}$ \\
\hline Child Female & $\begin{array}{l}0.03 \\
(0.9556)\end{array}$ & $\begin{array}{l}0.09 \\
(0.937)\end{array}$ & $\begin{array}{l}0.03 \\
(0.955)\end{array}$ & $\begin{array}{l}0.88 \\
(1.494)\end{array}$ & $\begin{array}{l}1.14 \\
(1.485)\end{array}$ & $\begin{array}{l}1.07 \\
(1.48)\end{array}$ \\
\hline Year $=2008$ & $\begin{array}{l}0.91^{* *} \\
(0.318)\end{array}$ & $\begin{array}{l}0.98^{* *} \\
(0.446)\end{array}$ & $\begin{array}{l}0.95^{* *} \\
(0.451)\end{array}$ & $\begin{array}{l}0.21 \\
(0.270)\end{array}$ & $\begin{array}{l}1.12^{*} \\
(0.546)\end{array}$ & $\begin{array}{l}1.13^{*} \\
(0.548)\end{array}$ \\
\hline
\end{tabular}




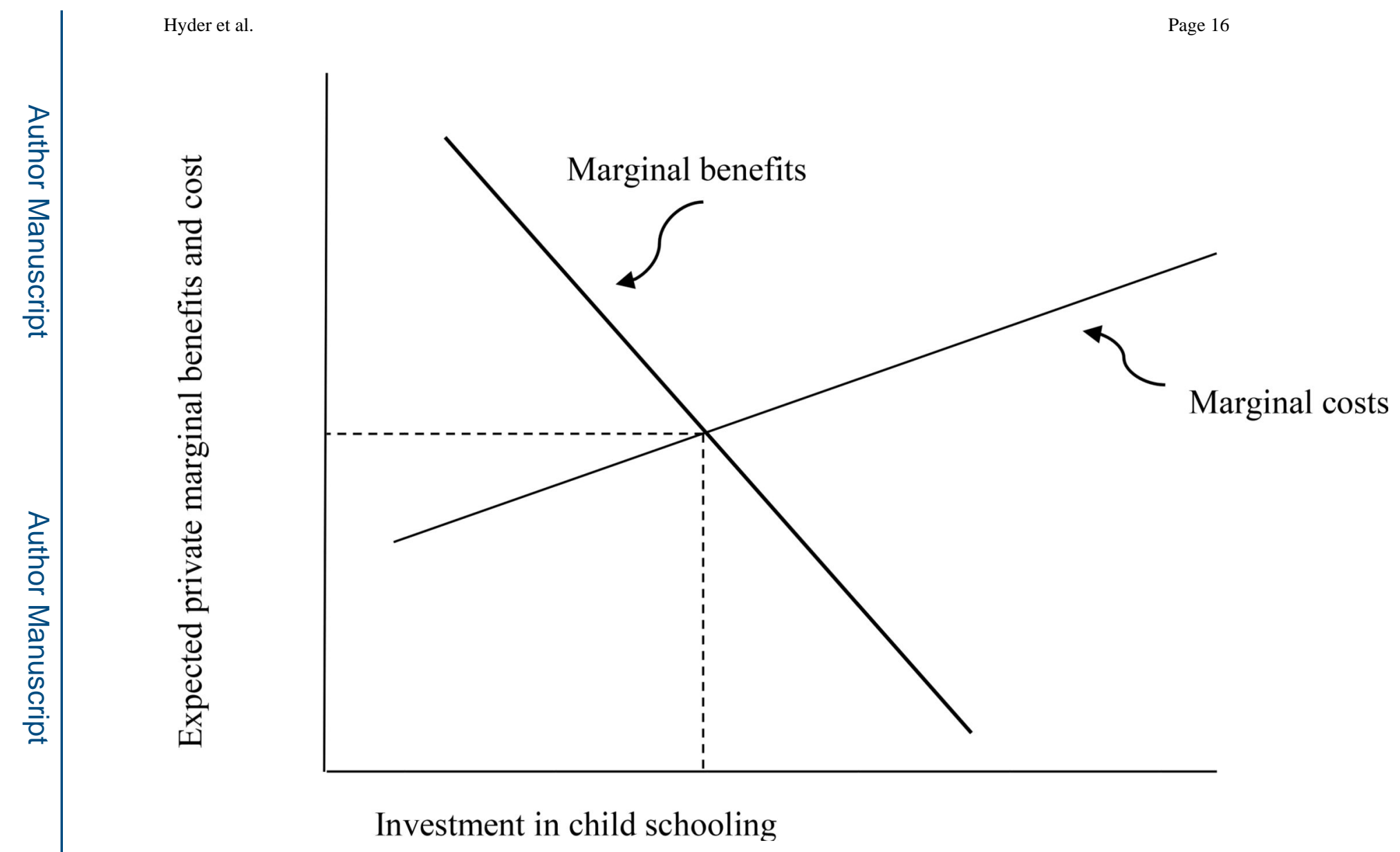

Figure 1.

Expected Private Marginal Benefits and Costs for Investment in Children's Schooling 


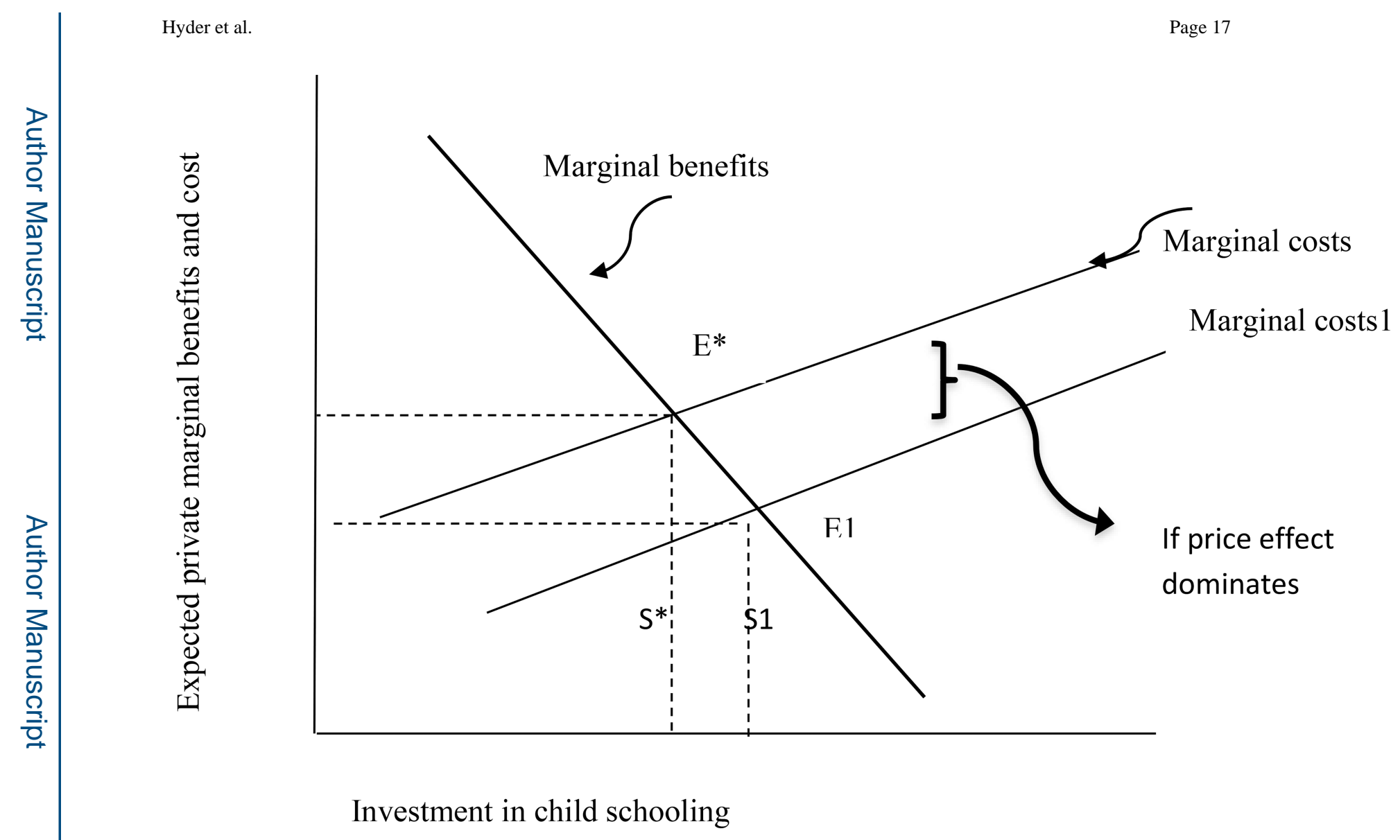

Figure 2.

Expected Private Marginal Benefits and Costs for Investment in Children's Schooling (If price effect dominates) 


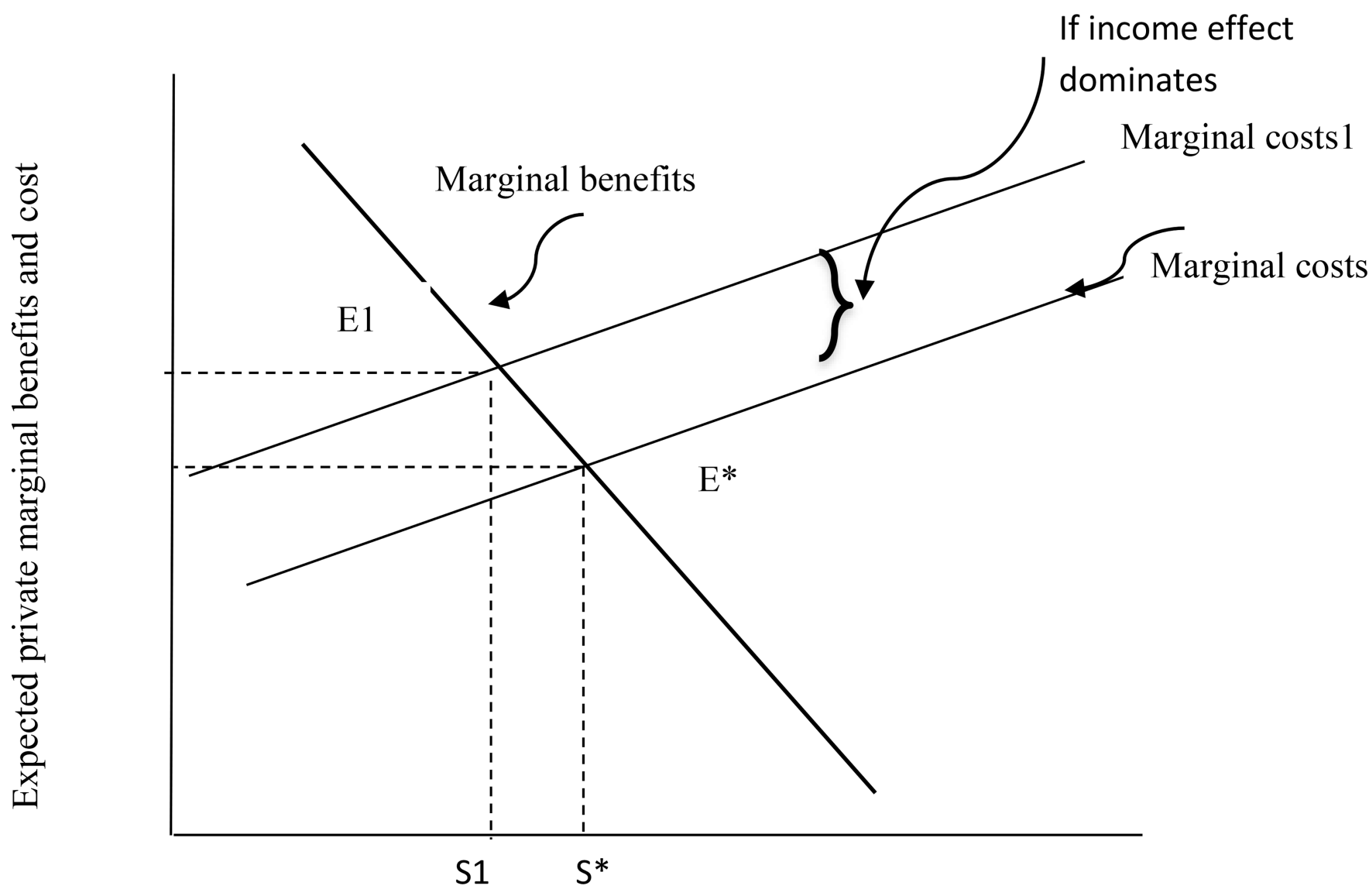

Investment in child schooling

Figure 3.

Expected Private Marginal Benefits and Costs for Investment in Children's Schooling (Income Effect Dominates) 


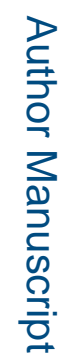

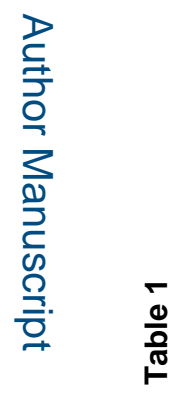

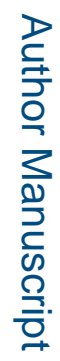

\begin{tabular}{|c|c|c|c|c|c|c|c|c|c|c|c|c|c|c|c|c|c|c|c|}
\hline \multirow{2}{*}{ 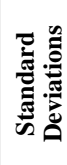 } & ڤ్ & 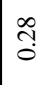 & लि & $\stackrel{\Re}{-}$ & $\stackrel{\vec{\infty}}{-}$ & के & గొర & $\stackrel{ \pm}{0}$ & $\stackrel{ \pm}{0}$ & 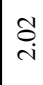 & $\stackrel{+}{\sigma}$ & ?ִ & $\stackrel{\infty}{+}$ & $\hat{m}$ & $\stackrel{\imath}{\imath}$ & $\begin{array}{l}0 \\
n \\
0\end{array}$ & 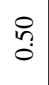 & Sָ & ते \\
\hline & ఫัڤ & m̂n & m? & $\stackrel{\bar{\infty}}{-}$ & $\stackrel{n}{\stackrel{n}{*}}$ & gे & ఫे. & $\frac{9}{0}$ & $\stackrel{े}{\circ}$ & $\stackrel{\infty}{\rightarrow}$ & $\stackrel{\curvearrowright}{\Omega}$ & $\stackrel{f}{q}$ & $\stackrel{\infty}{+}$ & గి & $\overparen{\overbrace{}}$ & ñ & ?n & $\underset{\text { gे }}{\text { i }}$ & ले \\
\hline \multirow{2}{*}{ 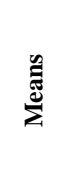 } & ڤ్ & $\bar{\delta}$ & $\stackrel{\mathscr{a}}{\stackrel{\infty}{\circ}}$ & $\stackrel{\infty}{\infty}$ & $\frac{\Re}{i}$ & $\begin{array}{c}\vec{\infty} \\
0 \\
0\end{array}$ & $\underset{\stackrel{\infty}{\infty}}{\stackrel{0}{\infty}}$ & م્ & 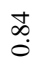 & m. & $\stackrel{5}{0}$ & $F$ & : & $\fallingdotseq$ & 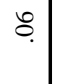 & $\stackrel{g}{0}$ & ?: & $\begin{array}{l}\stackrel{\square}{\infty} \\
\stackrel{\Theta}{\Theta}\end{array}$ & $\stackrel{\infty}{\varrho}$ \\
\hline & క్సે & $\begin{array}{l}\infty \\
\infty \\
0\end{array}$ & $\begin{array}{l}\stackrel{0}{\infty} \\
\stackrel{0}{0}\end{array}$ & $\begin{array}{l}\text { aे } \\
\hat{i}\end{array}$ & $\begin{array}{l}\hat{a} \\
\hat{i}\end{array}$ & के & $\begin{array}{l}\text { f. } \\
0\end{array}$ & ले & 吕 & $\stackrel{3}{3}$ & $\stackrel{7}{0}$ & $?$ & $\stackrel{8}{0}$ & $\because$ & 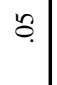 & 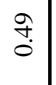 & fे & $\stackrel{\infty}{\sim}$ & $\stackrel{m}{\varrho}$ \\
\hline & 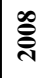 & $\stackrel{\infty}{g}$ & 范 & 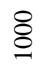 & ơ & 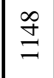 & 赵 & 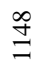 & $\begin{array}{l}\infty \\
\stackrel{0}{\circ}\end{array}$ & $\stackrel{\infty}{\stackrel{\infty}{\circ}}$ & $\begin{array}{l}\bar{\infty} \\
\stackrel{\leftrightarrow}{n}\end{array}$ & $\stackrel{\infty}{\Xi}$ & $\begin{array}{l}\infty \\
\stackrel{0}{\circ} \\
\stackrel{0}{2}\end{array}$ & 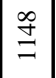 & $\begin{array}{l}\infty \\
\stackrel{0}{\circ}\end{array}$ & $\stackrel{0}{\stackrel{0}{\Xi}}$ & $\begin{array}{l}\infty \\
\stackrel{\infty}{\circ} \\
\underline{0}\end{array}$ & $\stackrel{\infty}{\Xi}$ & 胥 \\
\hline & ڤั & $\stackrel{\text { fo }}{\underline{\theta}}$ & 过 & హ్ & $\begin{array}{l}\stackrel{\mathscr{O}}{\beth} \\
\stackrel{\Xi}{2}\end{array}$ & $\stackrel{8}{\circ}$ & : & \&े & : & $\overline{\bar{\infty}}$ & $\underset{g}{\text { I }}$ & $\stackrel{\circ}{\varrho}$ & 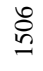 & $\stackrel{\leftrightarrow}{\stackrel{\circ}{\circ}}$ & $\begin{array}{l}8 \\
: \\
n\end{array}$ & $\stackrel{\circ}{\varrho}$ & $\stackrel{8}{\circ}$ & $\stackrel{8}{\circ}$ & 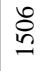 \\
\hline
\end{tabular}

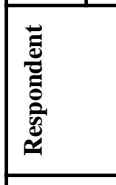

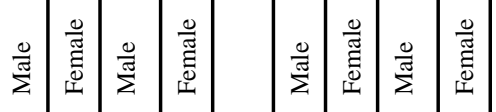

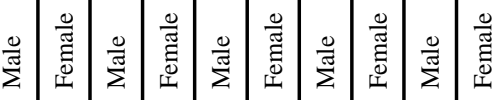

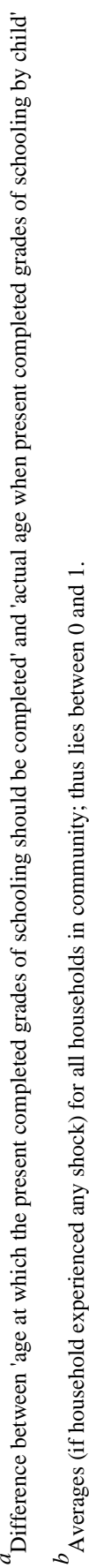

Dev South Afr. Author manuscript; available in PMC 2015 June 24. 


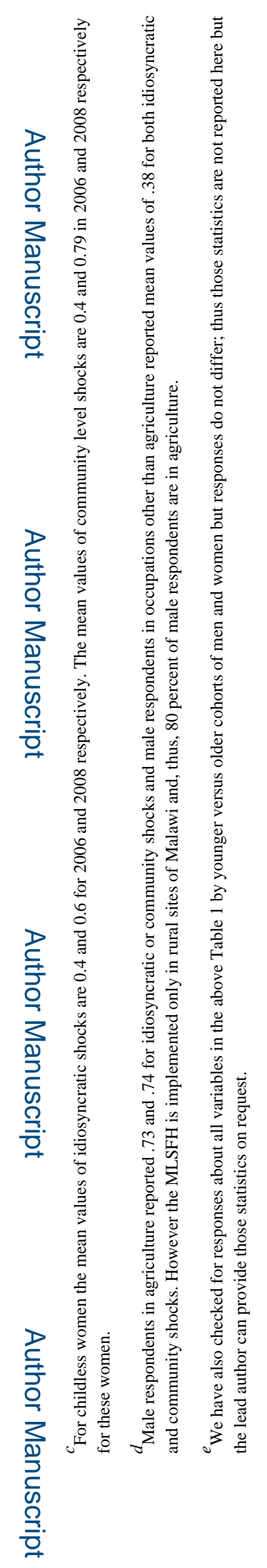

Dev South Afr. Author manuscript; available in PMC 2015 June 24. 


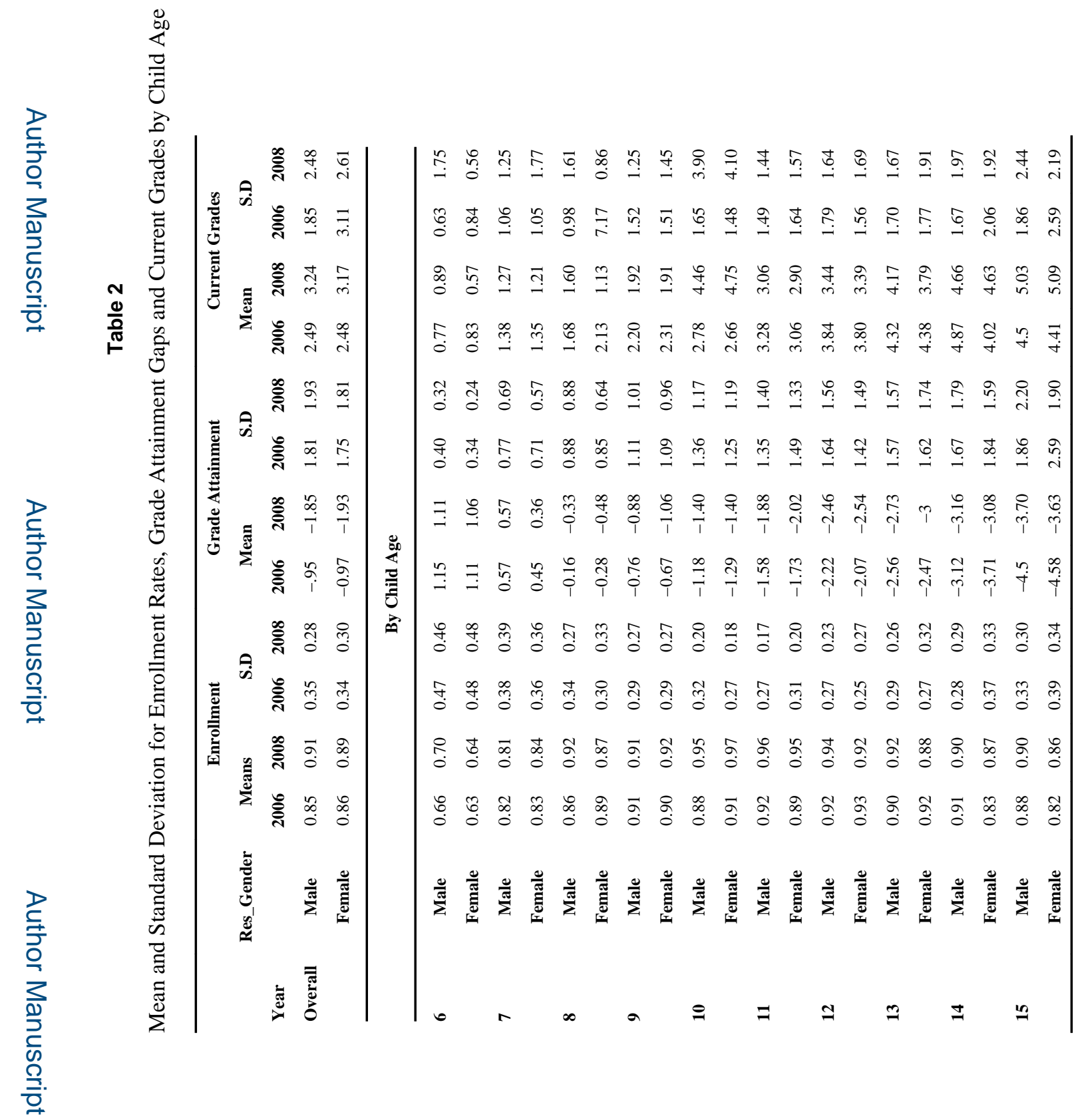

Dev South Afr. Author manuscript; available in PMC 2015 June 24. 


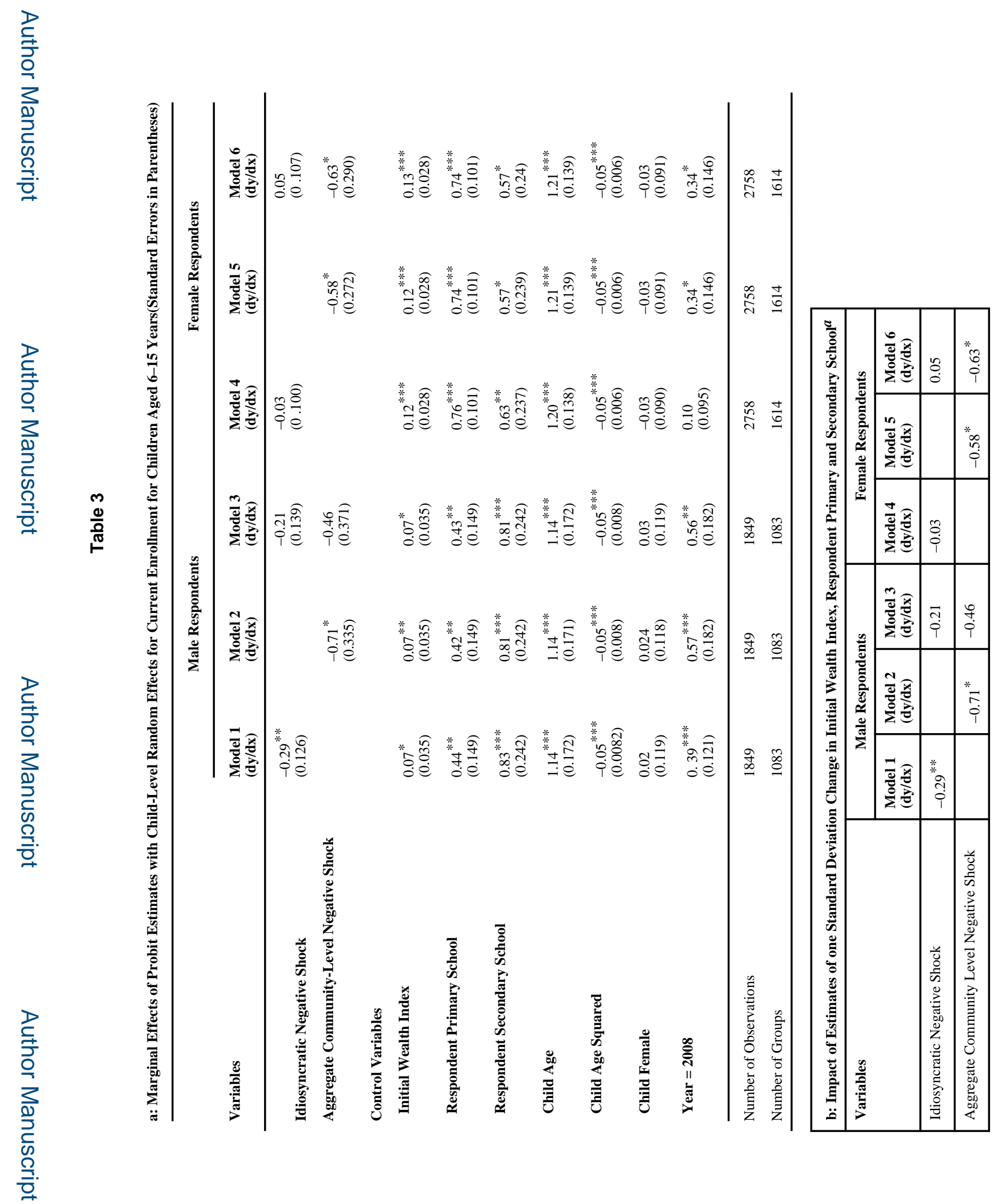

Dev South Afr. Author manuscript; available in PMC 2015 June 24. 


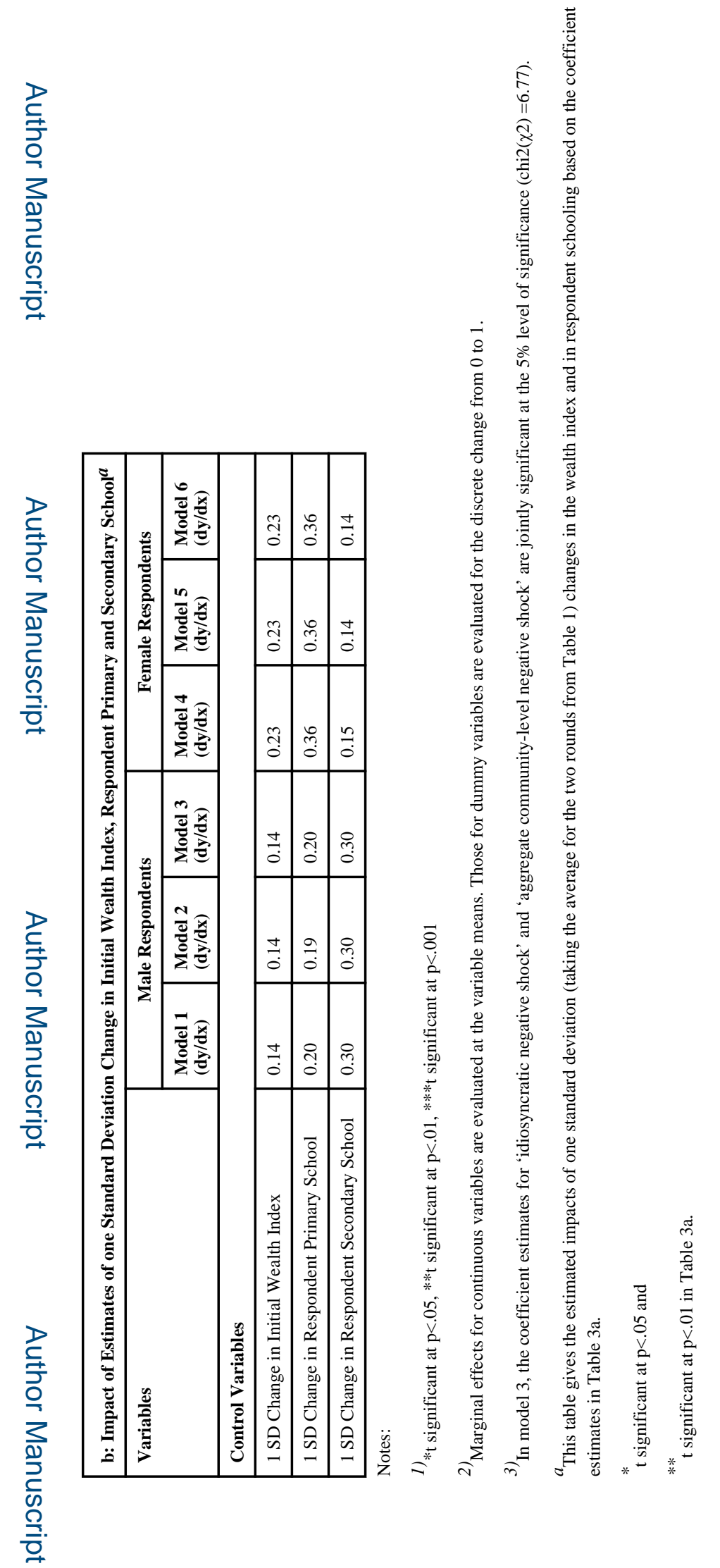

Dev South Afr. Author manuscript; available in PMC 2015 June 24. 


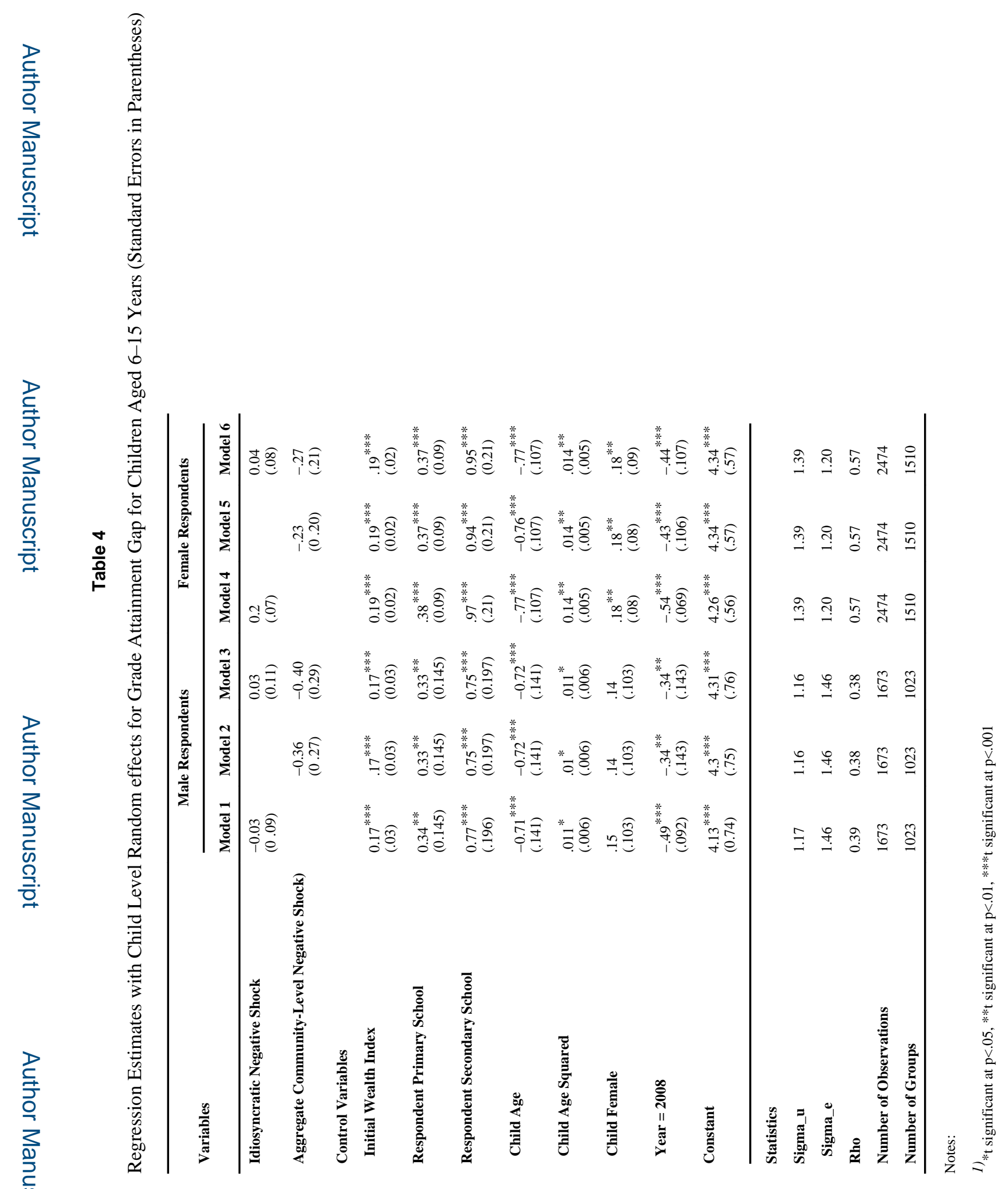

Dev South Afr. Author manuscript; available in PMC 2015 June 24. 